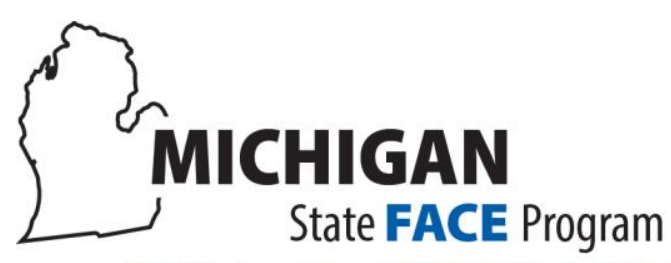

Fatality Assessment \& Control Evaluation

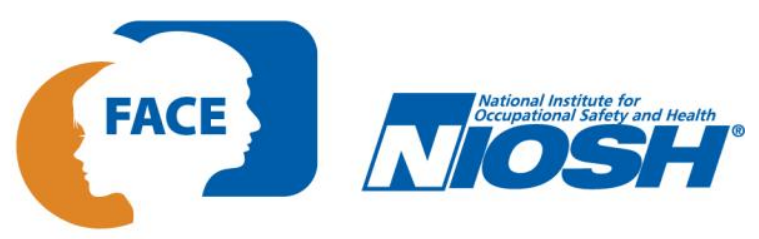

Michigan State University

Department of Medicine - Occupational and Environmental Medicine

909 Fee Road, 117 West Fee Hall • East Lansing, Ml 48824 • 1-517-353-1846 • https://oem.msu.edu

INCIDENT HIGHLIGHTS

DATE:

Fall, 2018

TIME:

Approximately 12:00 p.m.

VICTIM:

Construction Firm Owner in his 60s

INDUSTRY/NAICS CODE: Construction/23

EMPLOYER:

Plaster/Drywall Installation

SAFETY \& TRAINING:

On-the-Job

SCENE:

Warehouse Renovation

LOCATION:

Michigan

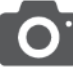

EVENT TYPE:

Fall

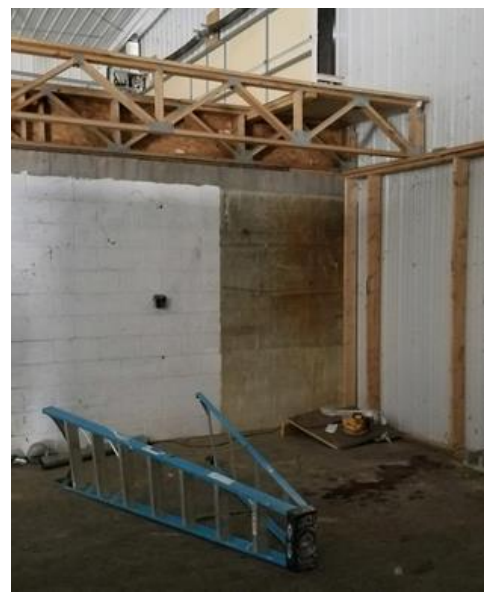

REPORT\#: 18MI105

REPORT DATE: $7 / 7 / 20$

\section{Construction Firm Owner Dies From Fall From 8-Foot Step Ladder Or Overhead Platform}

\section{SUMMARY}

In Fall 2018, a construction firm owner in his 60s died when he fell from either an 8-foot step ladder or an elevated platform to a concrete floor. While standing on the ladder, the decedent was using a compressor-powered saw, cutting foam panels and a wood platform/overhead truss system. The incident was unwitnessed. His son, who was working outside, heard a "crash" and ran inside of the building to find the source of the noise. When he arrived, he saw the ladder had tipped over and the decedent face down on the concrete floor ......READ THE FULL REPORT > (p.3)

\section{CONTRIBUTING FACTORS}

Key contributing factors identified in this investigation include:

- Working from a ladder rather than an appropriate work platform

- Improper ladder selection and use

- Appropriate personal protective equipment not worn $\underline{\text { LEARN MORE }>(p .7)}$

\section{RECOMMENDATIONS}

MIFACE investigators concluded that, to help prevent similar occurrences, employers should:

- Develop and implement an accident prevention program, including a job safety analysis to identify and minimize hazards.

- Minimize the use of ladders as a work platform. $\underline{\text { LEARN MORE }>}$ (p.7)

https://oem.msu.edu 


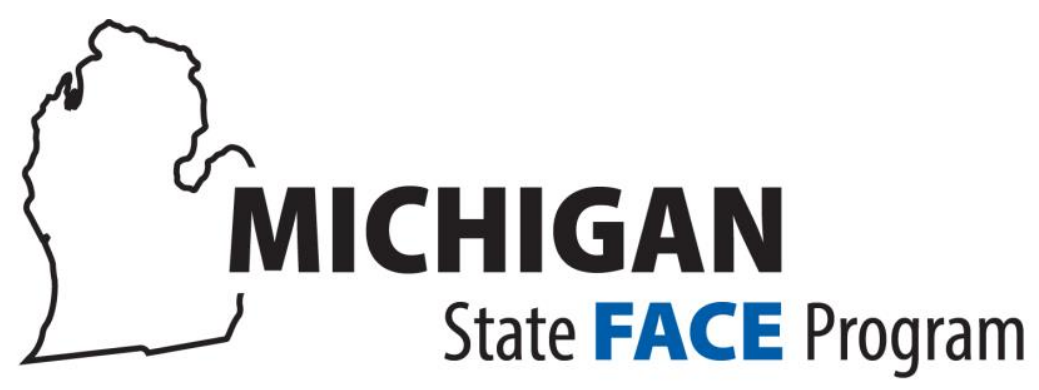

Fatality Assessment \& Control Evaluation

Michigan State University

Department of Medicine - Occupational and Environmental Medicine

909 Fee Road, 117 West Fee Hall • East Lansing, Ml 48824

1-517-353-1846 • https://oem.msu.edu
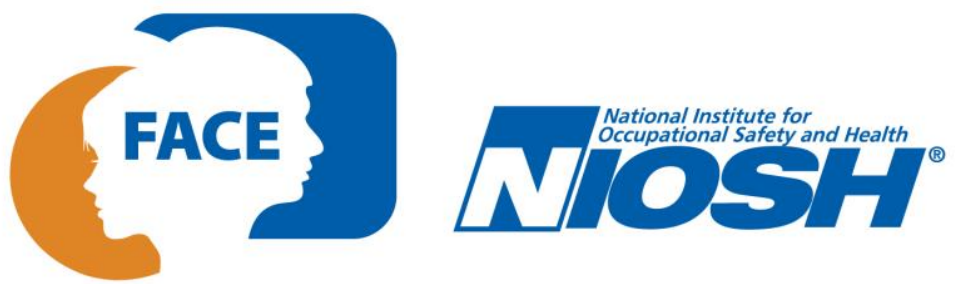

Michigan Fatality Assessment and Control Evaluation (FACE) Program

MIFACE (Michigan Fatality Assessment and Control Evaluation), Michigan State University (MSU) Occupational \& Environmental Medicine, 909 Fee Road, 117 West Fee Hall, East Lansing, Michigan 48824-1315; http://www.oem.msu.edu.

This information is for educational purposes only. This MIFACE report becomes public property upon publication and may be printed verbatim with credit to MSU. Reprinting cannot be used to endorse or advertise a commercial product or company. All rights reserved. MSU is an affirmative-action, equal opportunity employer. 


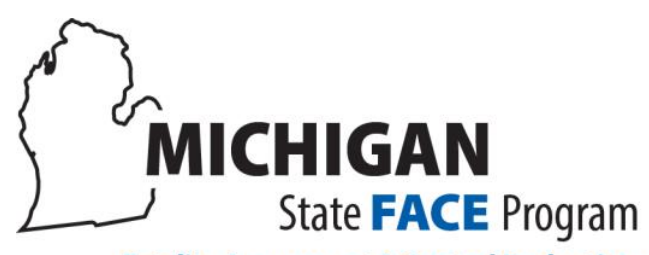

Fatality Assessment \& Control Evaluation

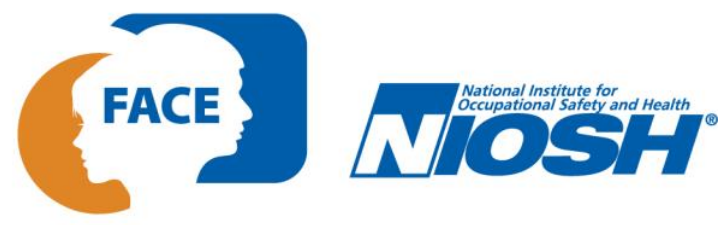

Michigan State University

Department of Medicine - Occupational and Environmental Medicine

909 Fee Road, 117 West Fee Hall • East Lansing, Ml 48824 •1-517-353-1846• https://oem.msu.edu

\section{SUMMARY}

In Fall 2018, a construction firm owner in his 60s died when he fell from either an 8-foot step ladder or an elevated platform to a concrete floor. The decedent was using a compressor-powered saw, cutting foam panels and a wood platform/overhead truss system. The incident was unwitnessed. His son, who was working outside, heard a "crash" and ran inside of the building to find the source of the noise. When his son arrived, he saw the ladder had tipped over. The decedent had landed on his head and was face down on the concrete floor. The coworker called for emergency response. The decedent was on his hands and knees, rocking back and forth when emergency response arrived. The decedent was transported to a nearby hospital where he succumbed to injury complications several days later.

\section{INTRODUCTION}

In Fall 2018, a construction firm owner in his 60s died when he fell from either an 8-foot step ladder or an elevated platform to a concrete floor. MIFACE learned of this death from the MIOSHA fatality reporting system. The decedent's two sons agreed to discuss their father's death with the MIFACE investigator at the incident site. MIFACE reviewed the death certificate, medical examiner's report and the MIOSHA compliance officer file during the writing of this report. Pictures used in the report are courtesy of the MIOSHA compliance officer file, one of the decedent's sons who provided pictures he took at the time of the incident, and pictures taken by the MIFACE investigator at the time of the MIFACE visit.

\section{EMPLOYERS}

A building owner hired a general contractor to demolish/renovate a warehouse. The general contractor hired the decedent to perform part of the demolition work.

According to his sons, the decedent owned his general construction firm, located in another state, for 43 years. The firm provided both commercial and residential services. He performed mostly steel stud- and drywall-related work in commercial construction and had performed demolition activities at several mall/big box type stores. The decedent's firm advertised as a one-stop solution for build-outs, repairs, and ongoing maintenance for commercial properties. The firm also would supply staff to supplement client maintenance crews for time-sensitive projects that need to get done quickly.

The decedent hired his son, who owned his own company to assist him as a subcontractor for this demolition job. The son had received ladder training in high school. This was his first day on the job and his firm did not provide any tools at the jobsite.

\section{WRITTEN SAFETY PROGRAMS and TRAINING}

The decedent did not have a written accident prevention program (health and safety program). His sons indicated that he had just completed the necessary classes and had just received his building license for Michigan (MIFACE could not find a building license on the State of Michigan website).

\section{WORKER INFORMATION}

His sons indicated the decedent was very familiar with demolition activities. The sons did not indicate that the decedent had any "formal" construction safety training. 


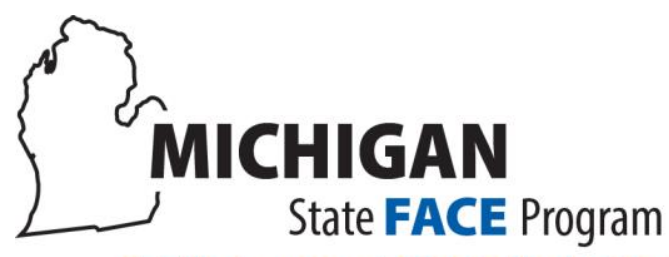

Fatality Assessment \& Control Evaluation

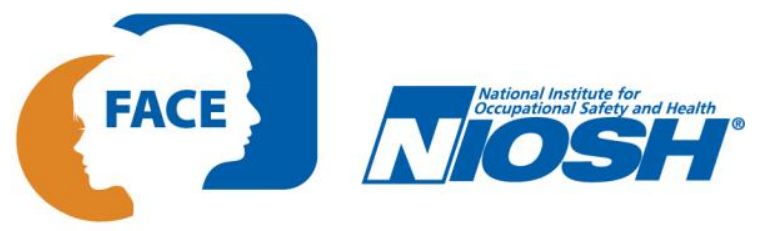

Michigan State University

Department of Medicine - Occupational and Environmental Medicine

909 Fee Road, 117 West Fee Hall • East Lansing, Ml 48824 • 1-517-353-1846 • https://oem.msu.edu

\section{INCIDENT SCENE}

The incident scene was inside of a warehouse undergoing demolition/renovation (Photo 1). The decedent was working from either an 8-foot step ladder positioned on a level concrete floor or from an elevated platform. If working from the ladder, based on his height, he most likely was standing on the third rung from the top. The decedent was using a compressor-powered saw to cut away foam-covered plywood platform positioned between two trusses/floor joists.

\section{WEATHER}

The incident occurred indoors. There was sufficient lighting.

\section{INVESTIGATION}

The general contractor contacted one of the decedent's son, who

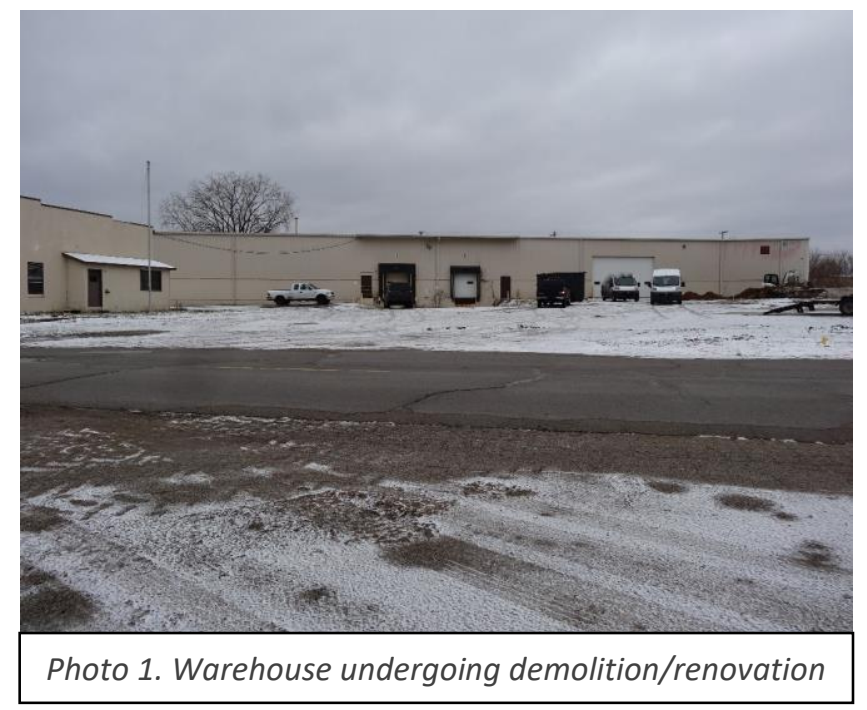
had his own construction business. The decedent's son thought it would be "great work for his dad's firm", so he arranged for his dad to contact the general contractor. The son, who was working at the site at the time of the incident indicated that the general contractor did not ask for a copy of the decedent's accident prevention program and did not provide any training to him regarding safety expectations, including hard hat use at this jobsite. The general contractor visited the site for approximately 5-10 minutes on the morning of the incident and spoke with the decedent. The general contractor provided a Bobcat skid steer and a generator for the power tools.

The decedent sent the following email to the general contractor outlining his scope of work: "In the demo I have included taking off tin roof and replacing after wall is finished. Remove drain from under wall, cut about 100 feet of concrete and remove to dumpster, tear out balcony and staircase. For the studs and drywall, we are looking at $14 \mathrm{~g}$ studs on demising wall with 3 layers on each side. Taping only the last layer. The $10 \mathrm{ft}$ areas are 20 ga with 1 layer of drywall on each side. Above the bath area to ceiling the walls will get studs with one layer of drywall each side. The ceiling in this area and the drying-transplant areas is a drywall suspension system with one layer of drywall around 9 feet. These areas will receive one coat of tape. Lifts, dumpsters, concrete saws and bobcat will be provided. All materials and labor will be provided."

The day of the incident was the decedent's second day at the

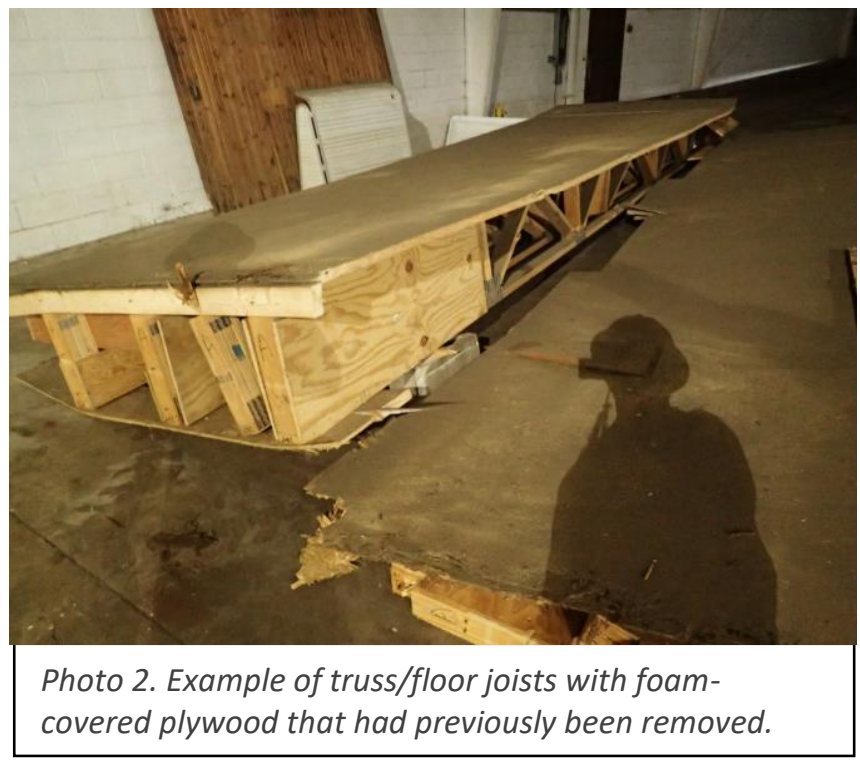
job site. It is unknown what work he performed on the first day. On the morning of the incident, at approximately 9:20 a.m. additional demolition work began. The son working on the site and the decedent discussed how to take down the trusses that spanned the room because the trusses/floor joists were to be saved. Exploring several options, they 


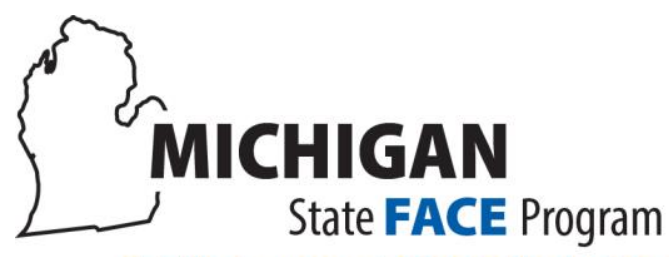

Fatality Assessment \& Control Evaluation

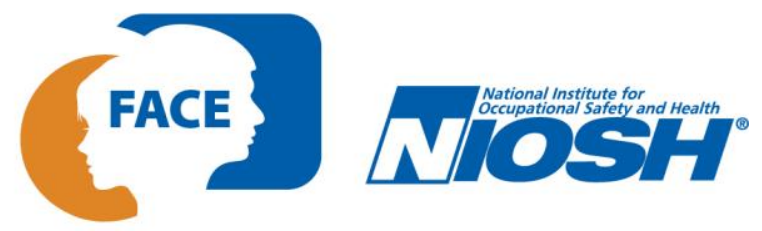

Michigan State University

Department of Medicine - Occupational and Environmental Medicine

909 Fee Road, 117 West Fee Hall • East Lansing, MI 48824 • 1-517-353-1846 • https://oem.msu.edu

ultimately decided to use to use a Bobcat to lift them up and twist them away from their attachment points, and then use the Bobcat to move them outdoors (Photo 2).

After the trusses were removed, the last truss (as described by the son as the most "dangerous" truss) required removal. The last two floor joists were associated with a 9-foot-high cement block wall (Photo 3). One of the two floor joists was positioned on the top of the cement block wall. They could not use the Bobcat to remove the truss because they did not want to damage the cement block wall.

The decedent removed the stairs that provided access to the foam insulation-covered plywood platform. He placed the 8 -foot Werner step ladder "inside" the two trusses/floor joists supporting the platform. He removed several sections of the plywood platform.

The incident was unwitnessed. Several incident scenarios include: 1) while working from the ladder, the decedent lost consciousness and fell to his right side; 2 ) the piece he was cutting fell unexpectedly, striking him and causing him to fall; 3) he had almost completed the cut, lost his balance (perhaps by overreaching or overexerting), and the force he exerted trying to regain his balance caused the board to break and the decedent to fall, 4) he was on top of the platform cutting the plywood/foam and potentially leaned on the piece being cut; when the cut was nearly complete or complete, the piece and the decedent fell to the ground, also striking the ladder causing it to tip to the side.

The decedent's fall occurred a few minutes after noon. His son was outside, working with the Bobcat as well as tearing the insulationcovered plywood floor from the previously-removed floor joists. He took a short break, and during this time, he heard the crash of the ladder and plywood hitting the floor, and then the compressor "go to idle" (the compressor idles when the saw is not in use). He ran to the source of the sound and found his father face down on the concrete floor. The ladder had tipped to the side. A piece of plywood was near his father, and the saw was laying on the plywood on the floor (Photo $3)$.

While inside the building he called 911 and kept getting disconnected; there was poor cell service both inside and outside the building.

After several minutes of call attempts to 911, the son went outside and was finally able to contact his brother who was a fire fighter/ EMT. The

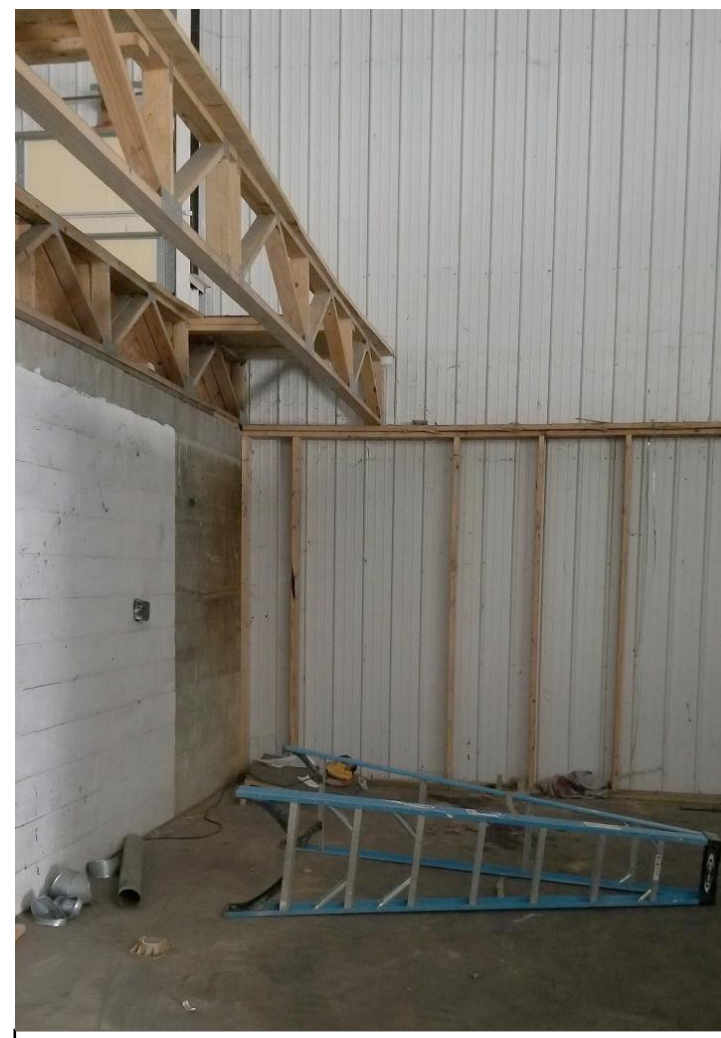

Photo 3. Incident scene showing ladder tipped to side, saw used at the time of the incident, and portion of elevated platform which fell. second son arrived approximately 12-13 minutes after receiving his brother's call. Emergency response (fire and police department) arrived approximately 7-10 minutes later. When the second son arrived, the decedent was on his hands and knees rocking back and forth. The son placed his hand on his father's back to keep him from rising further. His father did not respond to questions. 


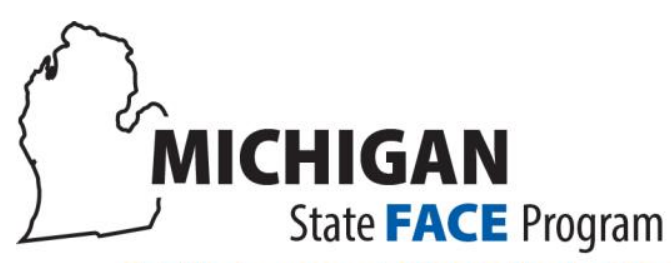

Fatality Assessment \& Control Evaluation

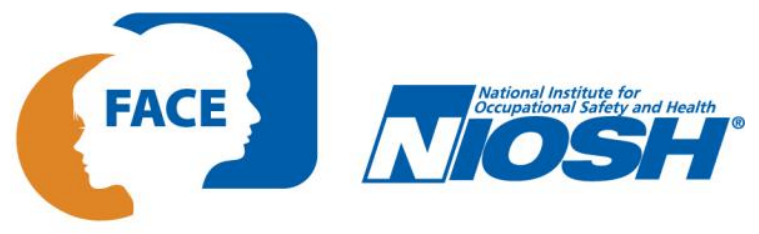

Michigan State University

Department of Medicine - Occupational and Environmental Medicine

909 Fee Road, 117 West Fee Hall • East Lansing, Ml 48824 • 1-517-353-1846 • https://oem.msu.edu

The second son indicated to the MIFACE researcher that the injuries his father sustained were not indicative of injuries of someone trying to break their fall or trying to block their head from hitting the floor during a fall.

The decedent was transported by emergency responders to a nearby hospital where he succumbed to injury complications several days later.

\section{MIOSHA Citations}

MIOSHA Construction Safety and Health Division did not issue a citation at the conclusion of its investigation due to the cessation of the business. The Division issued a Notice of Potential Hazard to the decedent's company at the close of the investigation.

\section{Notice of Potential Hazard:}

The following information is provided to the employer to correct an identified hazard. A MIOSHA rule violation exists, but employee exposure has not been determined or evidence is not sufficient to document a violation at this time.

Location: Within Warehouse @ Street Address, City, MI, Zip Code (MIFACE removed the Street Address, City and Zip Code)

Potential Hazard: While working in Michigan, please follow the requirements set forth in Construction Safety Standard Part 1; General Rules

R 408.40114 Employer responsibilities; accident prevention program. Rule 114. (1) An employer shall develop, maintain, and coordinate with employees an accident prevention program, a copy of which shall be available at the worksite.

Potential Hazard: While working in Michigan, please follow the requirements set forth in Construction Safety Standard Part 6: Personal Protective Equipment

1926.100(a) Employees working in areas where there is a possible danger of head injury from impact, or from falling or flying objects, or from electrical shock and burns, shall be protected by protective helmets.

Potential Hazard: While working in Michigan, please follow the requirements set forth in Construction Safety Standard Part 11: Fixed and Portable Ladders

R 408.41122 Use generally. (4) An employee shall face the ladder when ascending or descending. Each employee shall use at least 1 hand to grasp the ladder when progressing up or down the ladder. An employee shall not carry any object or load that could cause the employee to lose balance and fall.

Potential Hazard: While working in Michigan, follow Administrative Standard Part 11: Recording and Reporting of Occupational Injuries and Illnesses

408.22139 Reporting fatalities, hospitalizations, amputations, and losses of an eye as a result of work-related incidents to MIOSHA. Rule 1139. (1) Fatalities. Within 8 hours after the death of any employee from a workrelated incident, you must report the fatality by telephone to the MIOSHA toll-free central telephone number: 1800-858-0397. 


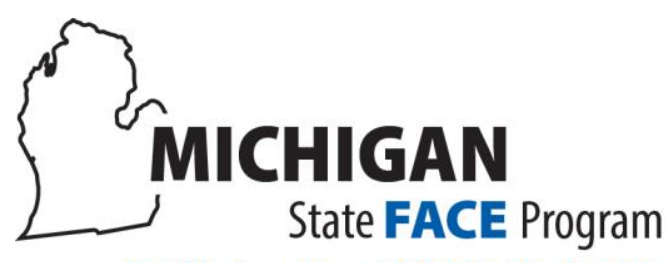

Fatality Assessment \& Control Evaluation

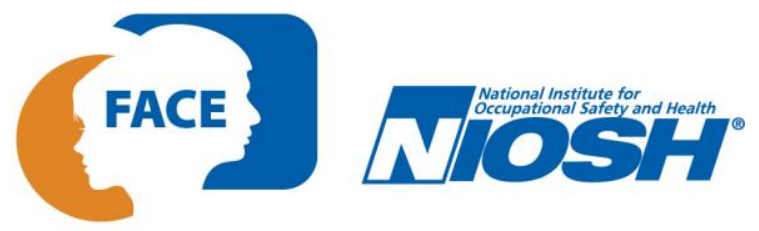

Michigan State University

Department of Medicine - Occupational and Environmental Medicine

909 Fee Road, 117 West Fee Hall • East Lansing, Ml 48824 • 1-517-353-1846 • https://oem.msu.edu

\section{CAUSE OF DEATH}

The death certificate listed the cause of death as brain death, due to or as a consequence of closed head injury due to or a consequence of a fall from ladder onto a concrete floor. No post-mortem toxicology was procured.

\section{CONTRIBUTING FACTORS}

Occupational injuries and fatalities are often the result of one or more contributing factors or key events in a larger sequence of events that ultimately result in the injury or fatality. The following hazards were identified as key contributing factors in this incident:

- Working from ladder rather than an appropriate work platform

- Improper ladder use and selection

- Appropriate personal protective equipment not utilized

- Did not perform a job hazard analysis

\section{RECOMMENDATIONS/DISCUSSION}

\section{Recommendation \#1: Employers should try to minimize the use of ladders as a work platform.}

Discussion: Firms should try to minimize the use of ladders as a work platform. Working from ladders can pose a fall hazard; therefore, ladders should be used for accessing higher and lower levels. If the task to be performed requires the worker to push, pull, or pry, then the use of scaffolding or aerial work platforms rather than a ladder is strongly recommended. The use of a ladder inherently limits the possible work area of a worker to an arm's length on either side of the ladder. Safe ladder use requires a worker to maintain a three-point connection (two hands/one foot or two feet/one hand) and his/her shoulders within the side rails. If the decedent was working from the ladder, he had to work outside the ladder rails to cut the foam-covered plywood and would have had to use both hands to operate the saw.

In general, when possible, use a scaffold or an aerial work platform, such as a scissor lift rather than a ladder to work from. Both a scaffold (not applicable in this incident) or a scissor lift (applicable in this incident) provide a larger work area, a more stable work platform, and reduced physical stress. In this incident, a scissor lift would enable the decedent to walk small distances safely and reduce the need for re-positioning the ladder to access a new work area. Because a worker can stand fully upright and use both hands for work procedures while having some protection from a fall due to the work surface railing, an additional safety factor is obtained with this type of equipment. Also, a larger work surface is available for the safer storage or positioning of tools and materials.

\section{Recommendation \#2: Ensure proper ladder selection and safe ladder use.}

Discussion: Proper ladder selection includes, not only ladder material, type of ladder, length/size of ladder, and the environment in which the ladder will be used, but also its duty rating. The duty rating is an indication of the maximum weight capacity the ladder can safely carry. The ladder user should determine the total amount of weight the ladder will be supporting, including the user's weight, weight of clothing and any protective equipment, weight of the tools and supplies, and the weight of any items stored on the ladder.

The decedent selected a Type 1 (Heavy Duty) step ladder from which to work. The maximum weight the ladder was designed to carry was 250 pounds. The decedent weighed more than 250 pounds. Overloading a ladder can result in ladder instability. A safer ladder selection for the decedent would have been a Type $1 \mathrm{~A}$ step ladder, which has a maximum carrying capacity of 300 pounds or a Type IAA (Extra Heavy Duty) ladder capable of supporting 375 pounds. 


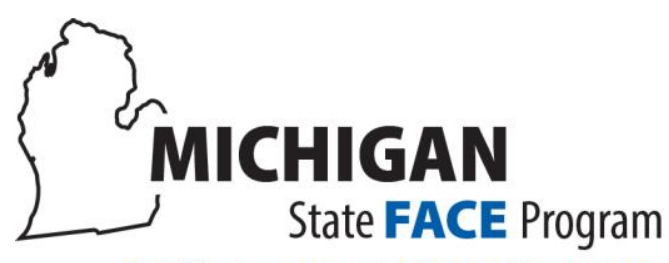

Fatality Assessment \& Control Evaluation

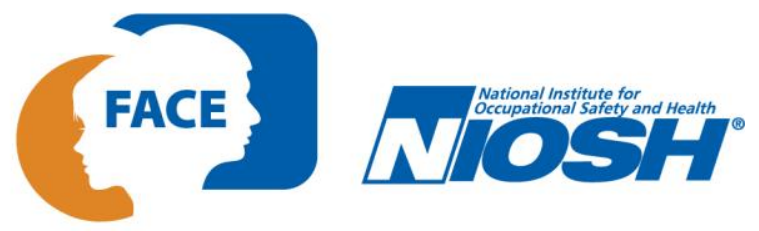

Michigan State University

Department of Medicine - Occupational and Environmental Medicine

909 Fee Road, 117 West Fee Hall • East Lansing, Ml 48824 • 1-517-353-1846 • https://oem.msu.edu

Employers and employees can learn more about ladder safety by downloading the NIOSH Ladder Safety App, a mobile application designed to improve extension and step ladder safety. The app is available for both Apple and Android phones. Information on the app, including the links to download the app to a mobile device can be found here.

\section{Recommendation \#3: Always use appropriate personal protective equipment.}

Discussion: The decedent was at an elevation, either from a ladder placed on a concrete floor or on top of the platform above the concrete floor. If he was working from the elevated platform, fall protection should have been utilized because he was working above a 6-foot height. If he was working from the ladder, due to the nature of the work, a hard hat would provide necessary head protection. If he had been wearing a hard hat, the hard hat might have taken much of the impact when he fell. Although he sustained other injuries, they were not life threatening; the head injuries were life threatening.

Recommendation \#4: Construction employers should develop and implement an accident prevention program. As a part of this program, a jobsite job safety analysis should be performed to determine hazards and hazard mitigation strategies and personal protective equipment.

Discussion: MIOSHA requires each construction employer to develop maintain, and coordinate with employees an accident prevention program (APP), a copy of which shall be available at the worksite. The APP must be written and kept up-to-date. MIOSHA requires that the plan be communicated to workers, so the workers know the company's safety rules and procedures. The APP must cover all of the different hazards that could be encountered during the work. One method of identifying these hazards is conducting a job safety analysis. A job safety analysis is a systematic process, as part of an implemented accident prevention program, to identify jobsite safety and health hazards so the hazard(s) can be minimized before work commences and while work progresses. It is unknown if the decedent performed a job hazard analysis prior to performing the work task. Even for "routine" tasks, it is a good work practice to stop and think about "what can go wrong?", identifying hazards and methods to minimize those hazards. If all workers would 1) Check your environment. 2) Have the knowledge to perform the task, 3) Check the equipment, and 4) Keep your mind on what you are doing, many injuries and deaths would be prevented/eliminated. people would think to do a simple task analysis before starting tasks a lot of accidents could be eliminated.

\section{RESOURCES}

- MIOSHA Resources:

- $\quad$ Stop Falls, Safe Lives webpage

- Construction Safety and Health Management System (Accident Prevention Program)

- Job Safety Analysis

- NIOSH Resources:

- Fatality Assessment and Control Evaluation (FACE) webpage. Searchable webpage for NIOSH and State FACE Investigation Reports.

- Falls in the Workplace webpage: https://www.cdc.gov/niosh/topics/falls/

- Ladder Safety App for Apple and Android mobile devices

- OSHA Resources:

- eTool: Construction Falls - Ladder Safety

- Ladder Safety: Reducing Falls in Construction: Safe Use of Stepladders Fact Sheet (OSHA FS-3662 - 2013)

- CPWR Resources: Stop Construction Falls: Safety Pays-Falls Cost webpage. https://stopconstructionfalls.com/ 


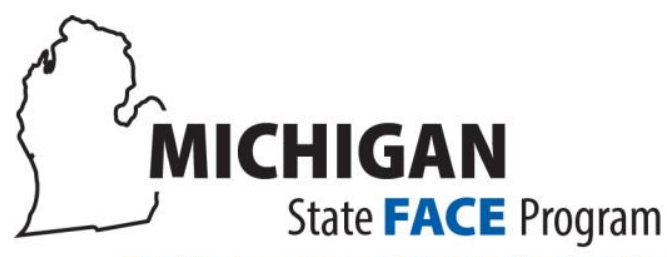

Fatality Assessment \& Control Evaluation

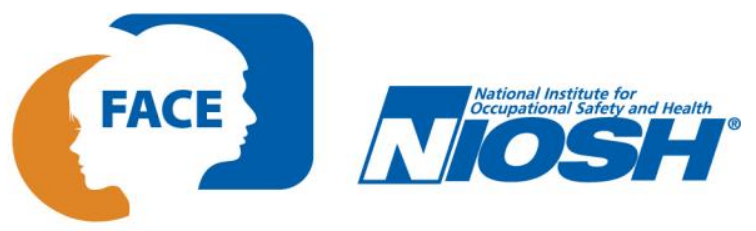

Michigan State University

Department of Medicine - Occupational and Environmental Medicine

909 Fee Road, 117 West Fee Hall $•$ East Lansing, Ml 48824 •1-517-353-1846 • https://oem.msu.edu

- American Ladder Institute: Ladders 101. https://www.americanladderinstitute.org/page/Ladders101

\section{DISCLAIMER}

Mention of any company or product does not constitute endorsement by the Michigan FACE program or the National Institute for Occupational Safety and Health (NIOSH). In addition, citations to websites external to NIOSH do not constitute $\mathrm{NIOSH}$ endorsement of the sponsoring organizations or their programs or products. Furthermore, NIOSH is not responsible for the content of these websites. All web addresses referenced in this document were accessible as of the publication date.

\section{REFERENCES}

MIOSHA standards may be found at and downloaded from the MIOSHA, Michigan Department of Labor and Economic Opportunity (LEO) website at: www.michigan.gov/mioshastandards. MIOSHA standards are available for a fee by writing to: Michigan Department of Labor and Economic Opportunity, MIOSHA Regulatory Services Section, 530 West Allegan, P.O. Box 30643, Lansing, Michigan 48909-8143 or calling (517) 284-7740.

- MIOSHA Construction Safety Standard, Part 1: General Rules

- MIOSHA Construction Safety Standard Part 6: Personal Protective Equipment

- MIOSHA Construction Safety Standard Part 11: Fixed and Portable Ladders

- MIOSHA Construction Safety Standard, Fall Protection: Part 45

- MIOSHA Administrative Standard Part 11: Recording and Reporting of Occupational Injuries and IIInesses

Gu, Ja K et al. Prevalence of work-site injuries and relationship between obesity and injury among U.S. workers: NHIS 20042012, J Safety Res. 2016 Sep; 58: 21-30.

Burkhart M., McCann M., Paine D. (2004) Elevated Work Platforms and Scaffolding: Job Site Safety Manual.

\section{ACKNOWLEDGEMEMENT}

The Michigan FACE Program would like to acknowledge the decedent's family for providing assistance and information for this investigation. 